ISSN: 1858-4837; E-ISSN: 2598-019X

Volume 15, Nomor 2 (2020),

https://jurnal.uns.ac.id/region

DOI: $10.20961 /$ region.v15i2.38063

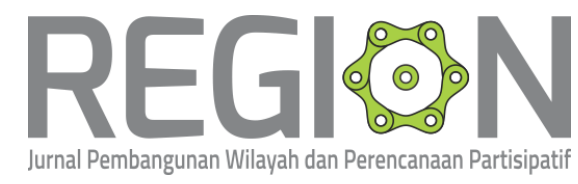

\title{
Model pertumbuhan kota (urban growth) di Kabupaten Manggarai Timur sebagai administrasi wilayah baru (startup)
}

\author{
The model of urban growth in East Manggarai Regency as startup region
}

\author{
A W Hasyim ${ }^{1}$, G Prayitno, and H I K Gusti ${ }^{1}$ \\ ${ }^{1}$ Departemen Perencanaan Wilayah dan Kota, Fakultas Teknik, Universitas Brawijaya
}

Corresponding author's email: awahidhs@ub.ac.id

\begin{abstract}
Abstrak. Kabupaten Manggarai Timur merupakan hasil pemekaran wilayah dari administrasi Kabupaten Manggarai tepatnya pada tanggal 17 Juli 2017. Jumlah penduduk di Kabupaten Manggarai Timur semakin meningkat dan berdampak pada bertambahnya luas lahan terbangun di beberapa kawasan dengan berbagai fungsi. Hal ini rentan terhadap munculnya permasalahan kota di masa yang akan datang apabila tidak diatur dengan regulasi yang kuat. Sehingga diperlukan sebuah kajian penelitian untuk mengetahui faktor-faktor pemicu utama terjadinya perubahan tutupan lahan di Kabupaten Manggarai Timur. Penelitian ini menggunakan metode penginderaan jauh (Remote Sensing) dengan teknologi GIS Pengolahan Raster Citra Satelit 8 OLI Kabupaten Manggarai Timur dengan tanggal akuisi 22 Maret 2013 dan 11 November 2018. Sampel yang digunakan adalah kondisi lapangan di setiap desa. Berdasarkan hasil analisa bahwa pada tahun 2013 dan tahun 2018, pertumbuhan lahan terbangun di setiap desa sangat dipengaruhi oleh beberapa faktor yang paling berpengaruh yakni kemiringan lahan, kepadatan penduduk, jarak titik pusat desa dengan jalan kolektor terdekat, dan kekuatan pusat aktivitas disuatu kecamatan. Namun juga terdapat beberapa variabel yang mengalami perubahan arah pengaruh terhadap tumbuhnya lahan terbangun dari tahun 2013 hingga tahun 2018 yakni variabel badan air dan variable rumput dan semak. Hasil kesimpulan dapat dijadikan bahan untuk membuat regulasi pengembangan lahan terbangun di Kabupaten Manggarai Timur agar sesuai dengan standar aturan tata ruang.
\end{abstract}

Kata Kunci: Lahan Terbangun; Penginderaan Jauh; Pertumbuhan Kota; Regresi Linier Berganda

Received: December 17, 2019; Accepted: February 11, 2020; Available online: July 31, 2020

Copyright $\odot$ 2020, REGION: Jurnal Pembangunan Wilayah dan Perencanaan Partisipatif 


\begin{abstract}
East Manggarai Regency is the result of regional expansion of the Manggarai Regency administration precisely on July 17, 2017. The population in East Manggarai Regency is increasing and has an impact on the area of land developed in several regions with various functions. This is vulnerable to the emergence of city problems in the future if not regulated by strong regulations. So we need a research study to find out the main triggering factors for land cover changes in East Manggarai Regency. This research uses remote sensing method with GIS technology for OLI Satellite Raster Image Processing 8 in East Manggarai Regency with the acquisition date of March 22, 2013 and November 11, 2018. The sample used was field conditions in each village. Based on the results of the analysis that in 2013 and 2018, the growth of land developed in each village was greatly influenced by some of the most influential factors namely land slope, population density, distance of the village center point to the nearest collector road, and the strength of the activity center in a subdistrict. However, there are also some variables that have changed the direction of influence on the growth of built land from 2013 to 2018, namely the variable body of water and variable grass and bush. The conclusions can be used as material to make regulations on the development of construction in East Manggarai Regency to be in accordance with the standard spatial rules.
\end{abstract}

Keywords: Built Up Area; Multiple Linear Regression; Remote Sensing; Urban Growth

\title{
1. Pendahuluan
}

Kabupaten Manggarai Timur merupakan salah satu kabupaten yang terletak di Provinsi Nusa Tenggara Timur dan termasuk dalam wilayah Indonesia bagian tengah. Secara administrasi Kabupaten Manggarai Timur merupakan hasil dari pemekaran wilayah administrasi Kabupaten Manggarai. Pada tanggal 17 Juli 2007, secara resmi Kabupaten Manggarai terbagi menjadi Kabupaten Manggarai Barat dan Kabupaten Manggarai Timur. Hal ini bertujuan untuk melaksanakan amandat otonomi daerah untuk mempermudah melakukan pembangunan [1].

Sebagai wilayah kabupaten baru (startup), Kabupaten Manggarai Timur masih dalam proses pengembangan dan pembangunan dari berbagai aspek utama yakni aspek ekonomi, aspek sosial, aspek lingkungan, dan aspek budaya. Cullingswoth dalam Priambudi [2] menyampaikan bahwa jika hal tersebut dikaitkan dengan peningkatan jumlah penduduk yang terjadi, maka jumlah kebutuhan lahan untuk pembangunan fisik berupa lahan terbangun sebagai perwujudan dari proses pengembangan dan pembangunan wilayah juga akan semakin meningkat. Sebagai contoh dari aspek ekonomi, kebutuhan pengembangan sarana perdagangan dan jasa seperti pasar, pertokoan, dan retail lainnya juga akan semakin meningkat. Begitupula dengan aspek sosial, kebutuhan lahan untuk mewujudkan pembangunan berdasarkan aspek tersebut seperti pembangunan sekolah, rumah sakit, dan fasilitas umum lainnya juga akan semakin meningkat.

Seiring berjalannya waktu, pembangunan fisik berupa lahan terbangun (permukiman, fasilitas umum, dan retail) telah terjadi di berbagai kawasan dan menyebabkan beberapa kawasan hutan telah mengalami degradasi akibat perubahan lahan. Berdasarkan data statistik Kabupaten Manggarai Timur tahun 2018 terjadi pengurangan lahan vegetasi berupa degradasi

Received: December 17, 2019; Accepted: February 11, 2020; Available online: July 31, 2020 226

Copyright $\odot$ 2020, REGION: Jurnal Pembangunan Wilayah dan Perencanaan Partisipatif 
hutan di beberapa kawasan yakni sebagian besar terjadi di Kecamatan Borong dan Kecamatan Kota Komba dengan total luas degradasi masing-masing adalah 59,320\% (penurunan 600 ha dari 1140 ha) dan 32,200\% (penurunan 1124 ha dari 3688 ha). Perubahan tutupan lahan tersebut juga secara tidak langsung dipengaruhi oleh beberapa kondisi wilayah seperti kondisi infrastruktur, kondisi pusat aktivitas, kondisi tutupan lahan, dan kondisi geografis. Bertambahnya luas lahan terbangun di beberapa kawasan akan membentuk sebuah embrio kota yakni sebuah bibit awal (startup) terjadinya pertumbuhan kota (urban growth) [3].

Menurut Arsyad dalam Prihatin [4], pada beberapa kasus apabila suatu pertumbuhan kota (urban growth) tidak terkontrol oleh suatu regulasi yang kuat maka akan menimbulkan permasalahan serius dimasa yang akan datang. Contoh permasalahan yang sering terjadi adalah pemanfaatan lahan yang tidak sesuai dengan potensinya, seperti pemanfaatan ruang untuk vegetasi dan non vegetasi yang tidak sesuai dengan standar tata ruang. Beberapa dampaknya adalah memicu ketidakstabilan iklim mikro dan peningkatan kerentanan bencana banjir dan longsor pada kawasan tertentu [5]. Selain itu permasalah bisa menjadi lebih kompleks jika dilihat dari aspek sosial, ekonomi, dan lingkungan [6].

Perubahan tutupan lahan di Kabupaten Manggarai Timur saat ini sebagai dampak pertumbuhan kota, sehingga diperlukan sebuah kajian penelitian guna mengetahui faktorfaktor yang berpengartuh terhadap perubahan tutupan lahan, khususnya bertambahnya lahan terbangun atau kegiatan pertumbuhan kota. Melalui kajian tersebut dapat digunakan untuk prediksi pertumbuhan kota dan dapat dijadikan sebagai salah satu bahan dasar pembuatan rekomendasi pengembangan dan pembangunan di Kabupaten Manggarai Timur [7].

\section{Metode}

\subsection{Ruang lingkup wilayah studi}

Ruang lingkup pada penelitian ini fokus pada wilayah Kabupaten Manggarai Timur yang secara astronomis terletak antara $08^{\circ} .14^{\prime} \mathrm{LS}-09^{\circ} .00$ LS dan $120^{\circ} .20^{\prime}$ BT - $120^{\circ} .55^{\circ}$ BT. Peta administrasi Kabupaten Manggarai Timur dapat dilihat pada Gambar 1.

Luas wilayah Kabupaten Manggarai Timur sebagaimana tercantum dalam lampiran UndangUndang Nomor 36 Tahun 2007 tentang Pembentukan Kabupaten Manggarai Timur di Provinsi Nusa Tenggara Timur adalah seluas 2.642,93 Km² yang memiliki 9 Kecamatan, 17 Kelurahan, dan 159 Desa. Adapun unit sampel yang digunakan sebagai bahan analisa adalah administrasi desa. 


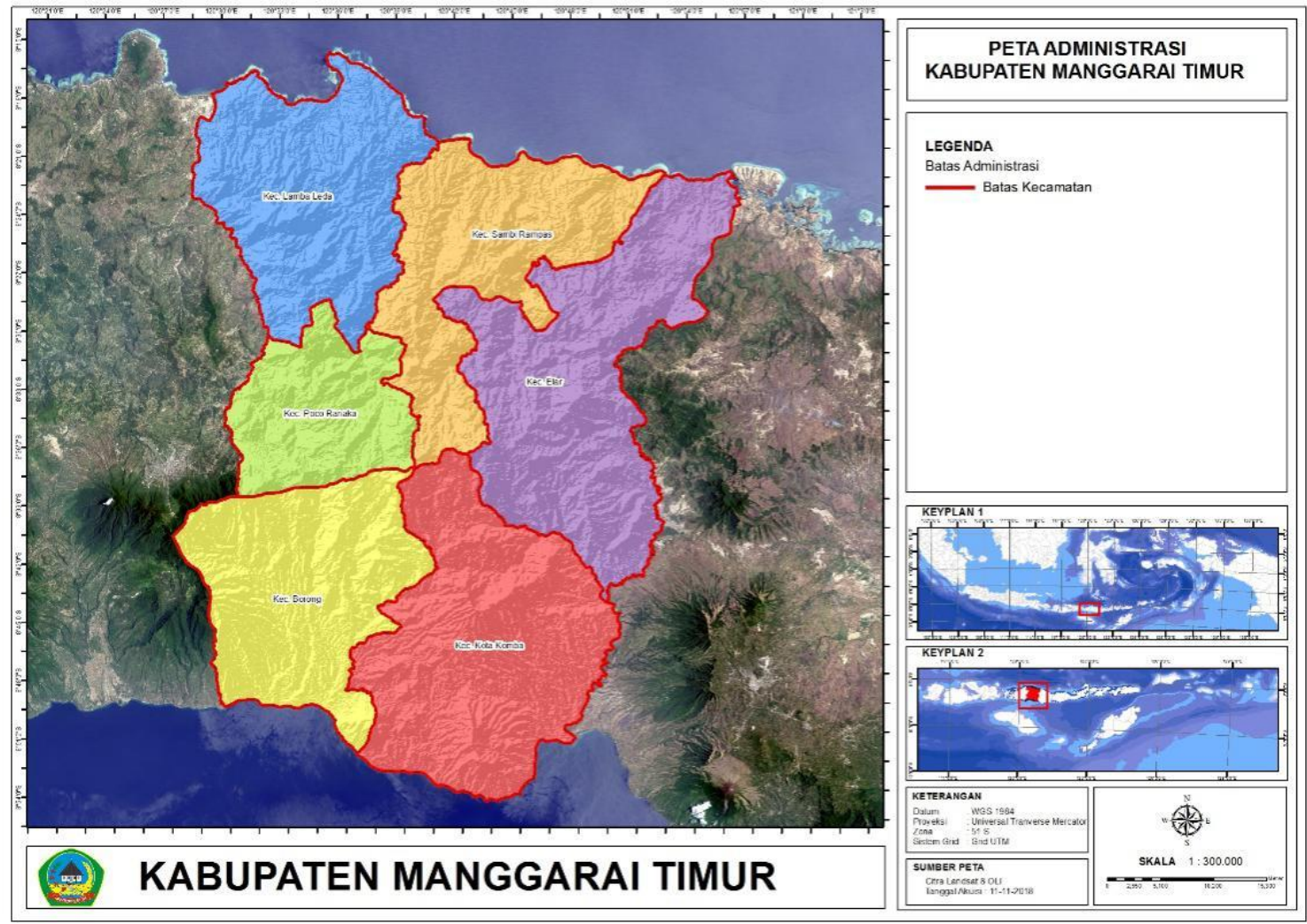

Gambar 1. Peta administrasi Kabupaten Manggarai Timur.

\subsection{Variabel yang digunakan}

Variabel yang digunakan dalam penelitian ini adalah sesuai dengan dugaan berdasarkan referensi yang telah didapatkan. Hasil referensi mengenai variabel yang mempengaruhi perubahan tutupan lahan tersebut kemudian diekstraksi dan dikembangkan untuk agar lebih spesifik. Adapun kumpulan referensi tersebut dapat dilihat pada Tabel 1.

Berdasarkan Tabel 1 dapat diketahui beberapa hasil ekstrasi variabel yang telah dilakukan. Hasil ekstraksi variabel tersebut kemudian dikembangkan secara spesifik dan dapat diukur dengan metode GIS dan Remote Sensing secara tepat dan akurat. Luas tutupan lahan terbangun di setiap desa akan digunakan sebagai variabel dependen. Sedangkan variabel independen yang diduga memiliki pengaruh terhadap luas lahan terbangun adalah kepadatan penduduk tiap desa tahun $t$ sebagai variabel $X 1$, pusat aktivitas dikembangkan menjadi kekuatan pusat aktivitas sebagai variabel X2, jarak terhadap jalan dikembangkan menjadi jarak setiap desa ke pusat aktivitas sebagai variabel X3, jarak setiap desa ke jalan kolektor sebagai variabel $\mathbf{X}$, dan jarak setiap desa ke jalan nasional sebagai variabel $X 5$, jarak setiap desa ke sungai terdekat sebagai $X 6$, kemiringan lahan (topografi) dikembangkan menjadi kemiringan rata-rata setiap desa dalam prosentase sebagai variabel $X 7$. Namun pada penelitian ini juga menggunakan variabel independen tambahan yang juga diduga memiliki pengaruh secara tidak langsung terhadap meningkatnya luas lahan terbangun yakni variabel guna lahan lainnya yang dikembangkan menjadi luas lahan badan air sebagai variabel $\mathrm{X} 8$, luas lahan terbuka 
sebagai variabel $X 9$, luas lahan pepohonan lebat sebagai variabel X10, luas lahan pepohonan sedang sebagai variabel $\mathrm{X} 11$, luas rumput dan semak sebagai variabel $\mathrm{X} 12$, dan luas sawah sebagai variabel X13.

Tabel 1. Referensi variabel yang mempengaruhi perubahan tutupan lahan menjadi lahan terbangun.

\begin{tabular}{ll}
\hline \multicolumn{1}{c}{ Teori } & \multicolumn{1}{c}{ Ekstraksi Variabel } \\
\hline Cullingswoth [8], empat faktor yang & 1. Kepadatan penduduk \\
mempengaruhi perubahan tutupan lahan yakni & 2. Pusat aktivitas \\
adanya konsentrasi penduduk dengan segala & 3. Jarak terhadap jalan \\
aktivitasnya, aksesibilitas terhadap pusat & 4. Jarak terhadap sungai \\
kegiatan dan pusat kota, jaringan jalan dan & \\
sarana transportasi, dan Orbitasi & \\
Chapin [9] juga mengungkapkan bahwa faktor- & 1. Kemiringan lahan \\
faktor yang mempengaruhi perubahan & 2. Guna lahan lainnya \\
penggunaan lahan yaitu topografi, penduduk, \\
nilai lahan, aksesbilitas, sarana dan prasarana \\
serta daya dukung lingkungan.
\end{tabular}

\subsection{Sumber data}

Sumber data yang digunakan terdiri dari dua macam yaitu data primer dan data sekunder. Data primer adalah penginderaan jauh (Remote Sensing) dengan menggunakan teknologi GIS. Penelitian ini menggunakan 2 temporal data citra satelit untuk membandingkan karakter variabel yang berpengaruh terhadap peningkatan luas lahan terbangun selama 5 tahun terakhir. Bahan yang diolah adalah Raster Citra Satelit 8 OLI Kabupaten Manggarai Timur dengan tanggal akuisi 11 November 2018 dan tanggal akuisi 22 Maret 2013. Sedangkan data sekunder adalah data yang didapatkan dari dokumen instansi terkait seperti Kecamatan Dalam Angka, Kabupaten Dalam Angka, dan RTRW Kabupaten Manggarai Timur. Adapun data sekunder yang dibutuhkan adalah jumlah penduduk pada tahun 2013 dan tahun 2018 di Kabupaten Manggarai Timur.

\subsection{Tutupan lahan}

Tutupan lahan di Kabupaten Manggarai Timur merupakan hasil dari klasifikasi terbimbing (Supervised Classification) Raster Citra Satelit Landsat 8 OLI Tahun 2018 dan Tahun 2013. Langkah pertama yang dilakukan adalah pembuatan training sample area pada raster sesuai dengan jenis klasifikasi yang diinginkan. Kemudian dilakukan proses klasifikasi dengan metode Maximum Likelihood Classification. Data luas jenis tutupan lahan setiap desa akan didapatkan setelah melakukan Calculate Geometry pada database shapefile tutupan lahan.

\subsection{Kemiringan lahan}

Bahan yang digunakan untuk mendapatkan data kemiringan lahan setiap desa adalah Raster DEM (Digital Elevation Model) Kabupaten Manggarai Timur. Data kemiringan diasumsikan 
tidak mengalami perubahan selama 5 tahun terakhir sehingga hanya menggunakan satu data raster. Langkah pertama yang dilakukan adalah pembuatan Slope Surface pada fitur software GIS. Satuan kemiringan yang digunakan adalah prosentase. Setelah menghasilkan data sebaran kemiringan lahan, maka akan dikalkulasi secara manual dengan menggunakan Ms. Excel untuk mendapatkan nilai kemiringan rata-rata setiap desa.

\subsection{Penghitungan jarak desa ke pusat aktivitas kecamatan}

Penghitungan jarak desa ke pusat aktivitas Kecamatan dilakukan dengan membuat garis penghubung (line shapefile) secara lurus antara titik pusat masing-masing desa dengan titik pusat desa sebagai pusat aktivitas di setiap kecamatan tersebut. Untuk mengeluarkan nilai ukuran jarak pada masing-masing garis maka dilakukan calculate geometry dengan satuan kilometer. Selain itu nilai kekuatan pusat aktivitas di setiap kecamatan didapatkan dari proses skoring dari 1 hingga 6 (6 kecamatan). Proses skoring diurutkan berdasarkan luas lahan terbangun pada desa yang menjadi pusat aktivitas di setiap setiap kecamatan.

\subsection{Penghitungan jarak antara desa dengan infrastruktur jalan kabupaten (jalan kolektor),} jalan nasional (jalan arteri sekunder), dan sungai terdekat

Penghitungan jarak desa ke jalan kolektor, jalan nasional, dan sungai terdekat dilakukan dengan membuat garis lurus yang menghubungkan antara titik pusat setiap desa ke bagian jalan nasional terdekat, bagian jalan kolektor terdekat, dan bagian sungai terdekat. Kemudian dilakukan kalkulasi geometrik untuk mendapatkan angka jarak pada garis tersebut. Sehingga proses penghitungan jarak lebih cepat dan akurat tanpa melakukan pengukuran secara manual.

\section{Hasil Penelitian dan Pembahasan}

\subsection{Tutupan lahan}

Tutupan lahan di Kabupaten Manggarai Timur diklasifikasikan sebanyak 6 jenis yakni lahan terbuka, lahan terbangun, badan air, sawah, rumput dan semak, pepohonan sedang, dan pepohonan lebat. Adapun sebaran perkembangan tutupan lahan di Kabupaten Manggarai Timur tahun 2013 dan 2018 dapat dilihat pada Gambar 2 dan Gambar 3. Sedangkan Selisih perubahan tutupan lahan Kabupaten Manggarai Timur tahun 2013 hingga tahun 2018 dapat dilihat pada Gambar 4. 


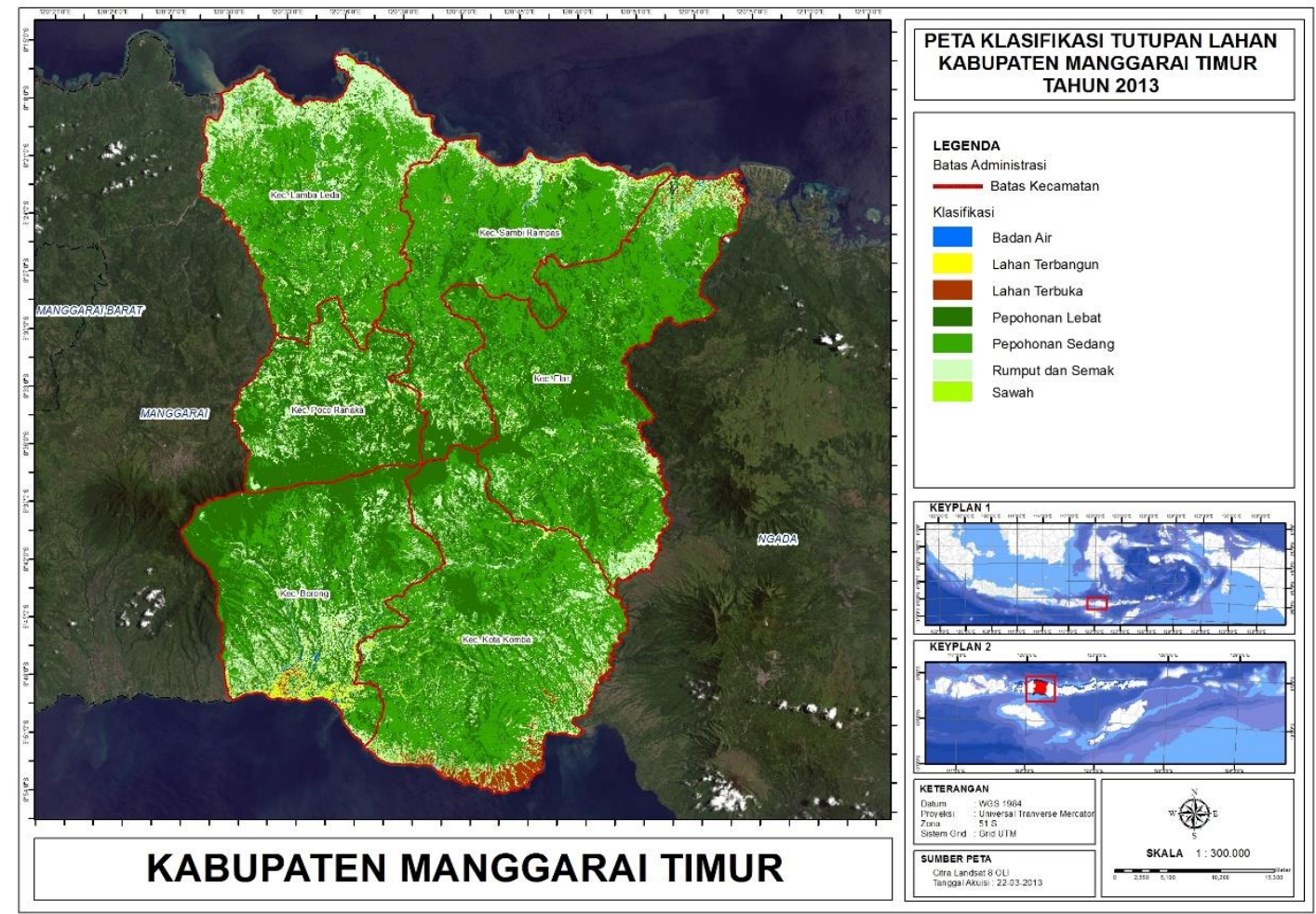

Gambar 2. Tutupan lahan Kabupaten Manggarai Timur tahun 2013.

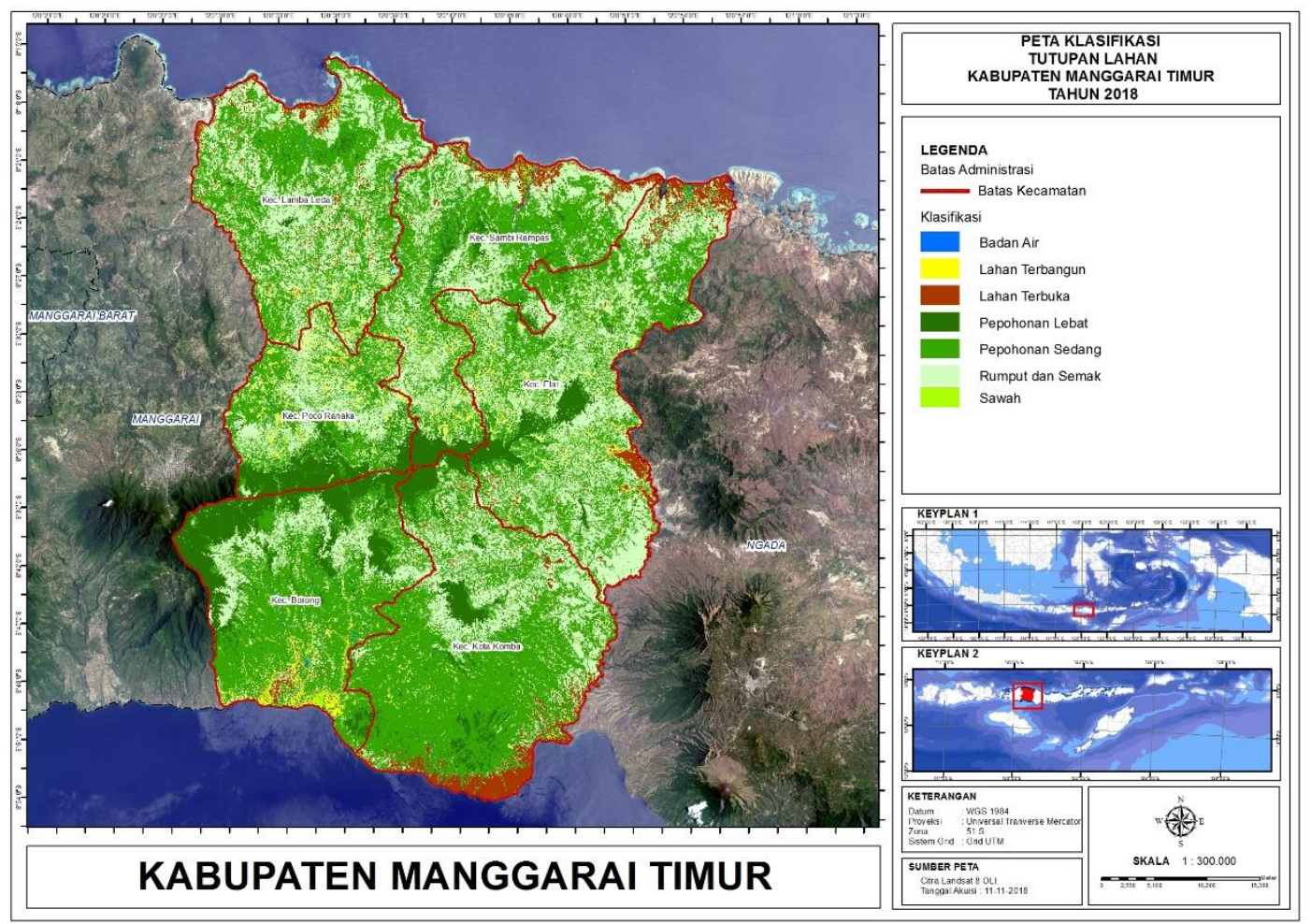

Gambar 3. Tutupan lahan Kabupaten Manggarai Timur tahun 2018. 


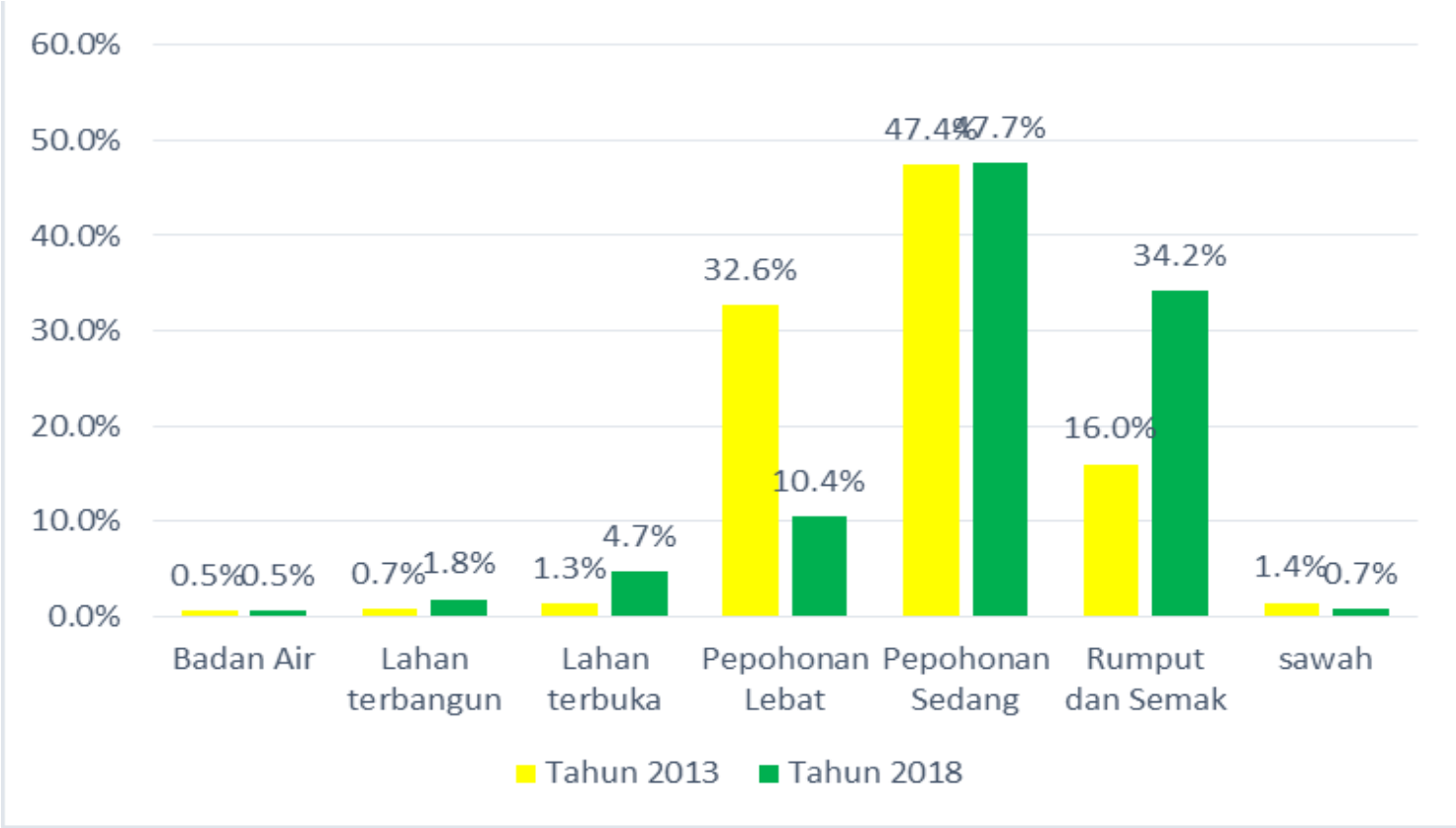

Gambar 4. Selisih perubahan tutupan lahan Kabupaten Manggarai Timur tahun 2013 hingga tahun 2018.

Berdasarkan Gambar 2, Gambar 3, dan Gambar 4 menginformasikan bahwa perubahan tutupan lahan di Kabupaten Manggarai Timur secara dominan terjadi pada perubahan luas tutupan lahan berkegiatan pepohonan lebat. Pada tahun 2013 tutupan lahan berkegiatan pepohonan lebat memiliki luas sebesar $32,6 \%$ atau seluas 78488,7 hektar menjadi $10,4 \%$ atau 25009,3 hektar pada tahun 2018. Bisa dikatakan tutupan lahan berkegiatan pepohonan lebat berkurang seluas 53479,4 hektar atau berkurang 68,1\% dari luas awal. Sedangkan lahan terbangun telah mengalami penambahan yakni dari luas sebesar 0,7\% atau 1699,7 hektar menjadi sebesar 1,8\% atau 4277,49 hektar (bertambah seluas 2577,8 hektar) yang sebagian besar tersebar di Kecamatan Borong sebagai pusat aktivitas Kabupaten Manggarai Timur.

\subsection{Kepadatan penduduk setiap desa di Kabupaten Manggarai Timur tahun 2013 dan tahun 2018}

Angka kepadatan penduduk adalah jumlah penduduk setiap desa dibagi dengan luas desa tersebut dengan satuan perhektar. Data kepadatan penduduk perkecamatan di Kabupaten Manggarai Timur tahun 2013 dan tahun 2018 dapat dilihat pada Tabel 2.

Tabel 2 menunjukkan terjadi peningkatan kepadatan penduduk pada beberapa kecamatan, yakni Kecamatan Kota Komba dengan kepadatan sebesar 1,02 perhektar pada tahun 2013 mengalami peningkatan menjadi 1,15 perhektar pada tahun 2018 atau memiliki selisih 0,134 perhektar. Sedangkan Kecamatan yang mengalami sedikit perubahan adalah Kecamatan Sambi Rampas dengan kepadatan sebesar 0,82 perhektar pada tahun 2013 berkurang menjadi 0,83 perhektar pada tahun 2018 atau dengan selisih kepadatan penduduk 0,011 perhektar. 
Tabel 2. Data kepadatan penduduk perkecamatan di Kabupaten Manggarai Timur tahun 2013 dan tahun 2018.

\begin{tabular}{lcc}
\hline \multirow{2}{*}{ Kecamatan } & \multicolumn{2}{c}{ Kepadatan Penduduk Per Hektar } \\
\cline { 2 - 3 } & Tahun 2013 & Tahun 2018 \\
\hline Borong & 0.89 & 0.97 \\
Elar & 0.33 & 0.38 \\
Kota Komba & 1.02 & 1.15 \\
Lamba Leda & 0.86 & 0.91 \\
Poco Ranaka & 1.41 & 1.51 \\
Sambi Rampas & 0.82 & 0.83 \\
\hline
\end{tabular}

\subsection{Kemiringan lahan rata-rata}

Kemiringan lahan di Kabupaten Manggarai Timur diklasifikan sebanyak 3 kelas untuk mempermudah kalkulasi dan interpretasi tingkat kemiringan lahan. Adapun tiga kelas tersebut antara lain $41^{\circ}$ hingga $60^{\circ}$ (sangat curam), $21^{\circ}$ hingga $40^{\circ}$ (kemiringan sedang), dan $0^{\circ}$ hingga $20^{\circ}$ (kemiringan landai). Hasil kalkulasi peta kemiringan lahan dengan menggunakan data raster DEM dapat dilihat pada Gambar 5.
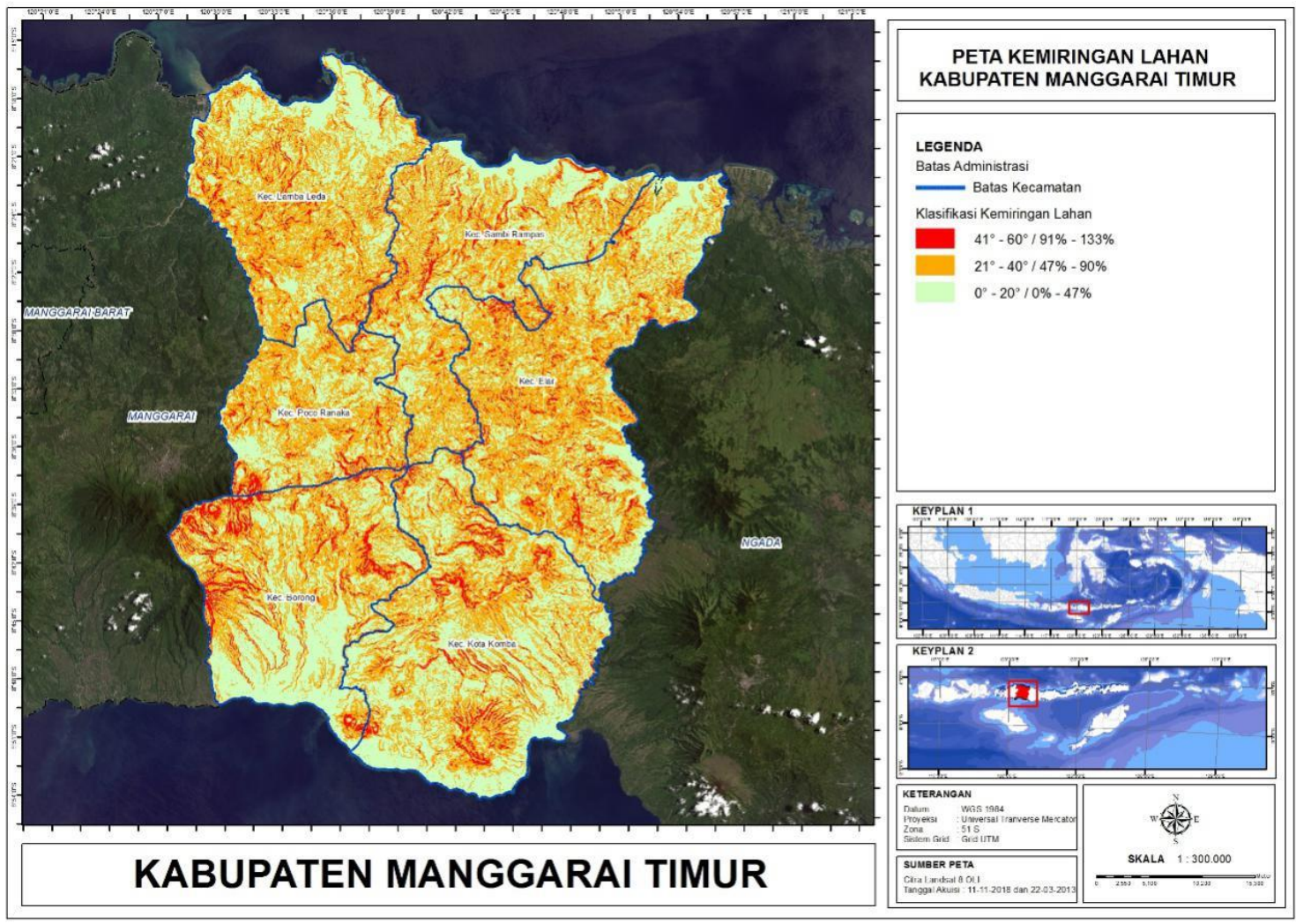

Gambar 5. Peta kemiringan lahan Kabupaten Manggarai Timur. 
Kemiringan lahan di Kabupaten Manggarai Timur didominasi oleh kemiringan antara $20^{\circ}$ hingga $40^{\circ}$ atau $47 \%-90 \%$, hal ini disebabkan sebagian besar kondisi topografi di Kabupaten Manggarai Timur merupakan kawasan pegunungan. Kawasan berwarna merah pada peta merupakan kawasan lahan yang memiliki kemiringan paling curam yakni berkisar antara $41^{\circ}$ hingga $60^{\circ}$ atau berkisar antara $91 \%$ hingga $133 \%$.

\subsection{Jarak titik pusat desa ke titik pusat desa sebagai pusat aktivitas di setiap kecamatan}

Jarak titik pusat desa ke titik pusat desa sebagai pusat aktivitas di setiap kecamatan dihitung dengan menggunakan line yang mana memiliki nilai koordinat dan dapat dihitung nilai panjang garis tersebut menggunakan kalkulasi geometri. Jarak tersebut dinilai sangat mempengaruhi potensi pertumbuhan guna lahan pada masing-masing desa. Berikut merupakan Gambar 6 peta jarak titik pusat desa dengan titik pusat kegiatan di setiap kecamatan.
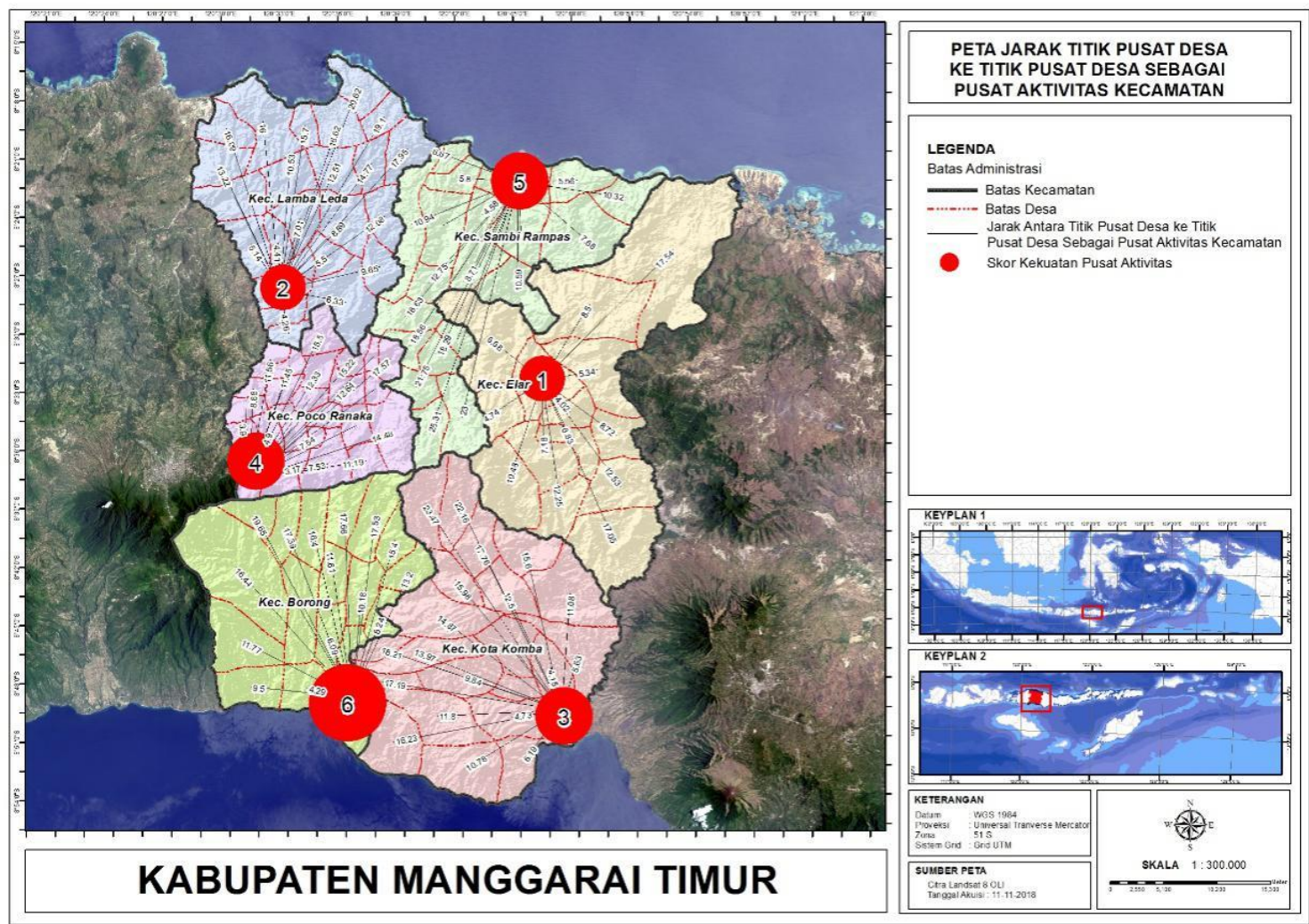

Gambar 6. Peta jarak titik pusat desa ke titik pusat desa sebagai pusat aktivitas kecamatan.

Berdasarkan Gambar 6 jarak antar desa dengan titik pusat aktivitas kecamatan tergantung dengan posisi administrasi desa di setiap kecamatan. Adapun kekuatan pusat aktivitas dari enam kecamatan tersebut yang paling tinggi adalah Kecamatan Borong. Hal ini dikarenakan jumlah luas lahan terbangun di pusat aktivitas tersebut diwujudkan dalam bentuk permukiman, sarana perdagangan dan jasa, fasilitas umum dan sarana pendukung lainnya yang lebih lengkap jika dibandingkan dengan kecamatan lainnya. Sedangkan kecamatan yang memiliki kekuatan pusat aktivitas yang paling rendah adalah Kecamatan Elar dan Kecamatan 
Lamba Leda. Hal ini diindikasikan dengan jumlah luas lahan terbangun pada kedua kecamatan tersebut paling sedikit.

\subsection{Jarak titik pusat desa ke jalan kolektor dan jalan nasional terdekat}

Jarak antara titik pusat desa dengan jalan kolektor maupun jalan nasional tentu sangat berpengaruh terhadap pertumbuhan lahan terbangun pada masing-masing desa. Dampak aksesbilitas akan mempengaruhi kemudahan penduduk dalam melakukan aktivitas ekonomi. Secara tidak langsung aktivitas tersebut akan berdampak apada kebutuhan lahan yang semakin meningkat. Meningkatnya kebutuhan lahan tentu akan berdampak pada perubahan alih funsgi lahan. Pada Gambar 7 dan Gambar 8 memvisualiasikan hasil pemetaan jarak titik pusat desa dengan jalan kolektor dan jalan nasional terdekat yang mana pada peta tersebut diambil contoh pada wilayah Kecamatan Kota Komba dan Kecamatan Borong.

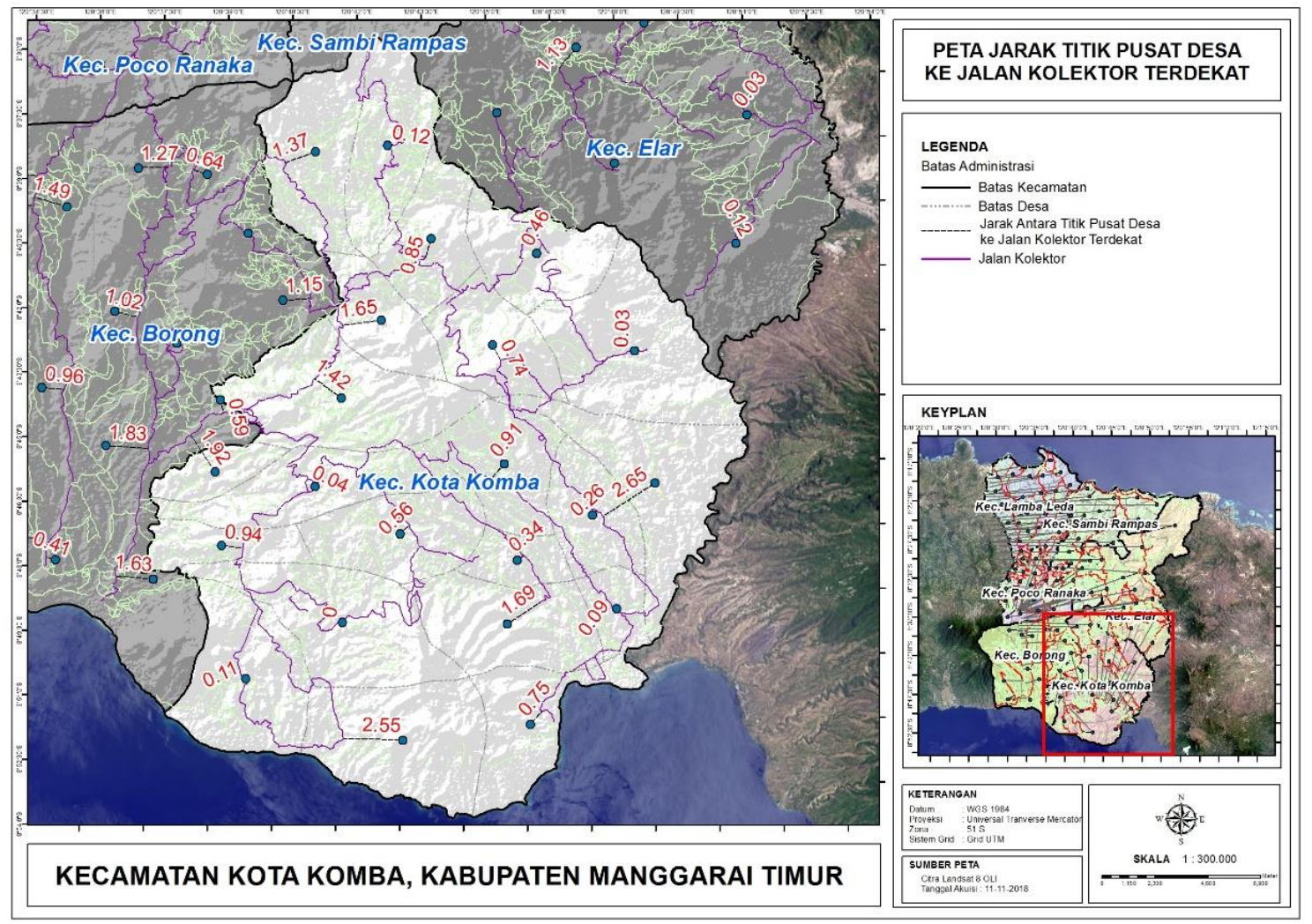

Gambar 7. Peta jarak titik pusat desa ke bagian jalan kolektor terdekat (tampilan peta terfokus pada Kecamatan Kota Komba).

Pada Gambar 7 dapat diidentifikasi bahwa terdapat beberapa administrasi desa yang tidak dilewati oleh jalan kolektor. Jalan kolektor tersebut memiliki status sebagai jalan kabupaten yakni penghubung antara kecamatan satu dengan lainnya. Desa yang memiliki jarak terdekat dengan jalan kolektor adalah Desa Nanga Mbaling, Kecamatan Sambi Rampas yakni dengan jarak 0,02 km dan Desa Pocong, Kecamatan Poco Ranaka dengan jarak 0,04 km. Desa yang 
memiliki keterdekatan dengan jalan kolektor tersebut diduga akan memiliki potensi pertumbuhan lahan terbangun yang lebih cepat daripada desa lainnya.

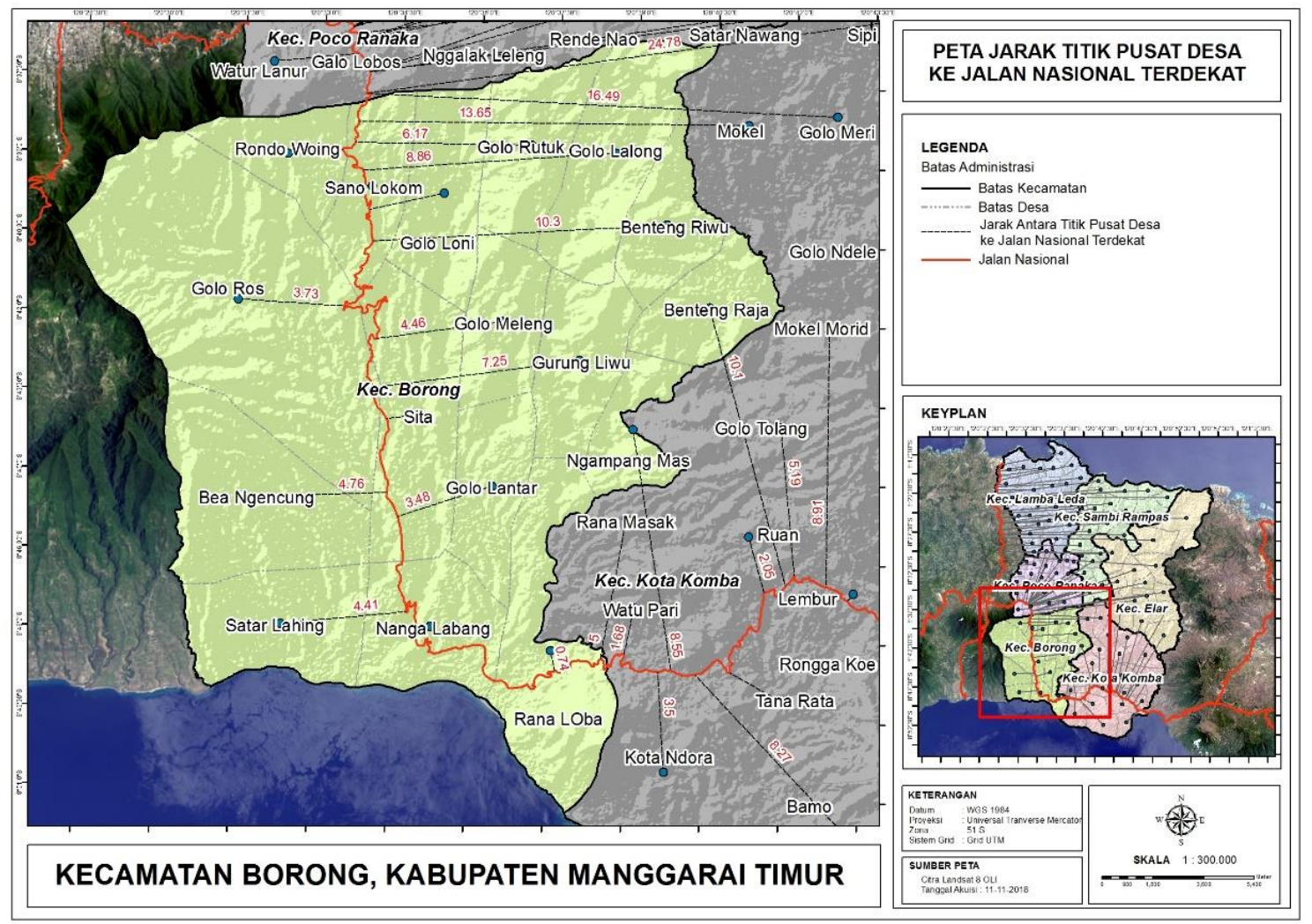

Gambar 8. Peta jarak titik pusat desa ke bagian jalan nasional terdekat (tampilan peta terfokus pada Kecamatan Borong).

Sedangkan pada Gambar 8 menunjukkan bahwa jalan nasional hanya melewati beberapa administrasi kecamatan dan desa. Kondisi eksisting jalan nasional di Kabupaten Manggarai Timur hanya memiliki lebar sebesar 6 meter. Desa yang memiiki jarak terdekat dengan jalan nasional tersebut adalah Desa Nanga Baras, Kecamatan Sambi Rampas dengan jarak 0,11 km, sedangkan desa yang memiliki jarak terjauh dengan jalan nasional adalah Desa Golo Lobos, Kecamatan Poco Ranaka dengan jarak sejauh 219,35 km. Jalan nasional dengan jalan kabupaten tentu memiliki bobot pengaruh pertumbuhan guna lahan yang berbeda. Jalan nasional dinilai lebih unggul memberikan dampak pertumbuhan guna lahan daripada jalan kabupaten.

\subsection{Jarak titik pusat ke sungai terdekat}

Secara historis sungai juga akan mempengaruhi tingkat perubahan guna lahan di sekitarnya. Kondisi aktivitas penduduk Kabupaten Manggarai Timur yang dinilai masih bermata pencaharian sebagai petani, tentu akan mempertimbangkan lokasi tempat tinggal dengan lokasi sungai. Hasil pengukuran jarak titik pusat desa dengan sungai terdekat dapat dilihat pada Gambar 9. 


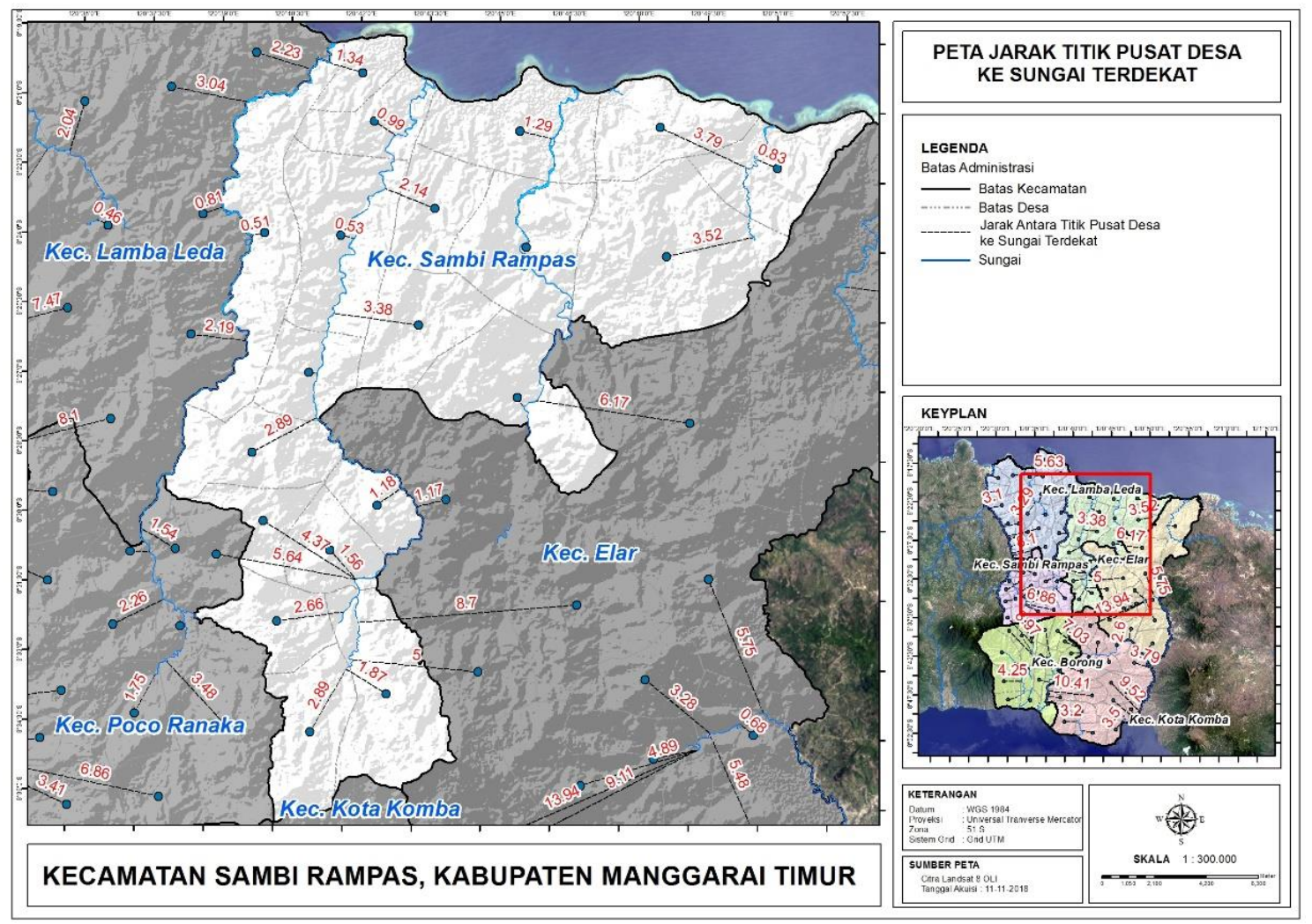

Gambar 9. Peta jarak titik pusat desa ke bagian jalan nasional terdekat (tampilan peta terfokus pada Kecamatan Sambi Rampas).

Berdasarkan Gambar 9 dapat diketahui bahwa desa yang memiliki jarak terdekat dengan sungai adalah Desa Nanga Mabalang, Kecamatan Sambi Rampas yakni berjarak 0,09 km dan Desa Golo Nderu, Kecamatan Poco Ranaka yakni berjarak 0,13 km. Sedangkan desa yang memiliki jarak terjauh dengan sungai terdekat adalah Desa Lembur dan Desa Golo Meni, Kecamatan Kota Komba yakni dengan jarak sejauh lebih dari 10 km.

\subsection{Analisis regresi linier berganda}

Sebelum dilakukan analisis regresi linier berganda perlu dilakukan uji asumsi klasik untuk mengetahui apakah data tersebut layak atau tidak untuk dianalisis. Analisis dilakukan pada dua kelompok data yakni data tahun 2013 dan tahun 2018 untuk membandingkan karakter pengaruh variabel independen pada perubahan lima tahun terkahir. Selain itu karakter model yang dihasilkan tentu akan memberikan data informasi yang sangat berguna dalam menentukan keputusan dalam perencanaan di Kabupaten Manggarai Timur. Berikut merupakan Tabel 3 hasil uji asumsi klasik pada kedua kelompok data. Hasil analisa uji normalitas dengan menggunakan metode Kolmogrov Sminorv pada Tabel 3 menunjukkan bahwa kedua kelompok data terdistribusi normal. Hal tersebut diindikasikan dengan nilai Kolmogrov Sminorv yang lebih dari 0,05. Hasil uji multikolinearitas dapat dilihat pada Tabel 4. 
Tabel 3. Hasil Uji normalitas.

\begin{tabular}{lccc}
\hline & \multicolumn{2}{c}{ Unstandardized Residual } \\
\cline { 2 - 4 } & & Data 2013 & Data 2018 \\
\hline$N$ & 98 & 98 \\
Normal Parameters ${ }^{a, b}$ & Mean & 0.0000000 & 0.0000000 \\
& Std. Deviation & $1.04725562 \mathrm{E} 2$ & 61.89861952 \\
Kolmogorov-Smirnov $Z$ & & 2.287 & 1.247 \\
Asymp. Sig. (2-tailed) & 0.000 & 0.000 \\
a. Data Terdistribusi Normal. & & \\
b. Data Terkalkulasi. & & \\
\hline
\end{tabular}

Tabel 4. Hasil uji multikolinearitas.

\begin{tabular}{lcccc}
\hline & \multicolumn{2}{c}{ Data 2013} & \multicolumn{2}{c}{ Data 2018} \\
\cline { 2 - 5 } & Sig. & VIF & Sig. & VIF \\
\hline Kepadatan_Penduduk & 0.006 & 1.572 & 0.003 & 1.310 \\
Pusat_Aktivitas & 0.043 & 1.187 & 0.009 & 1.137 \\
Jarak_Pusat_Aktivitas & 0.018 & 1.089 & 0.019 & 1.150 \\
Jarak_Jalan_Kolektor & 0.039 & 1.125 & 0.031 & 1.691 \\
Jarak_Jalan_Nasional & 0.039 & 1.353 & 0.033 & 1.365 \\
Jarak_Ke_Sungai & 0.017 & 1.167 & 0.020 & 1.299 \\
Kemiringan_Rata2 & 0.064 & 1.157 & 0.011 & 1.148 \\
Badan_Air & 0.006 & 1.765 & 0.033 & 2.159 \\
Lahan_Terbuka & 0.001 & 1.028 & 0.045 & 2.250 \\
Pepohonan_Lebat & 0.006 & 1.155 & 0.045 & 1.274 \\
Pepohonan_Sedang & 0.003 & 3.099 & 0.020 & 2.083 \\
Rumput_dan_Semak & 0.004 & 2.411 & 0.011 & 2.216 \\
Sawah & 0.006 & 1.719 & 0.002 & 1.812 \\
\hline
\end{tabular}

Dapat dilihat pada Tabel 4 bahwa nilai VIF pada kedua kelompok data adalah di bawah 10 sehingga kedua kelompok data tersebut bebas multikolinearitas. Scatter plot of heteroscedaticity test dapat dilihat pada Gambar 10.

Berdasarkan hasil uji heterosekdasitas, sebaran plot pada Gambar 10 terdistribusi menyebar dan tidak membentuk pola tertentu yang artinya bahwa kedua kelompok data tidak mengalami heterosekdasitas. Hasil uji metode Durbin Watson dapat dilihat pada Tabel 5.

Hasil uji autokorelasi pada Tabel 5 menunjukkan nilai Durbin Watson pada kedua kelompok data adalah 2,044 dan 2,049. Jika dibandingkan dengan skala Durbin Watson dengan jumlah sampel sebanyak 122 dan variabel sebanyak 14, maka kelompok data 2013 tersebut termasuk dalam skala tidak terjadi masalah autokorelasi. 


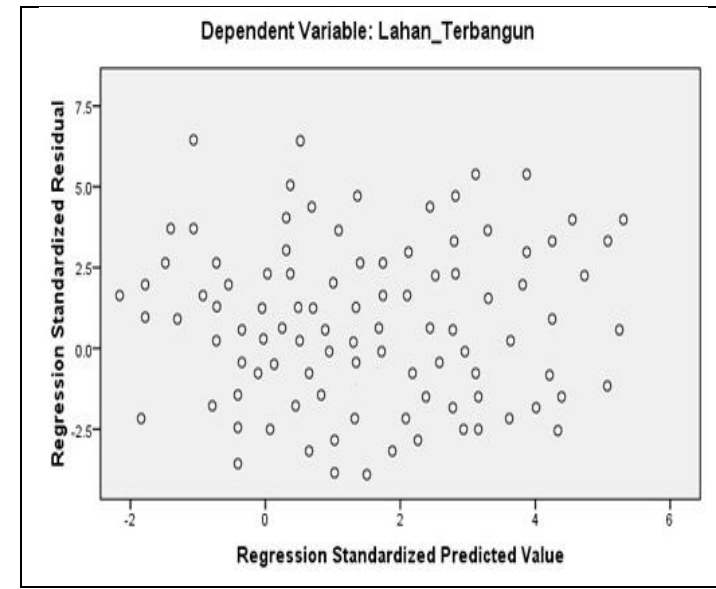

a. Data 2013

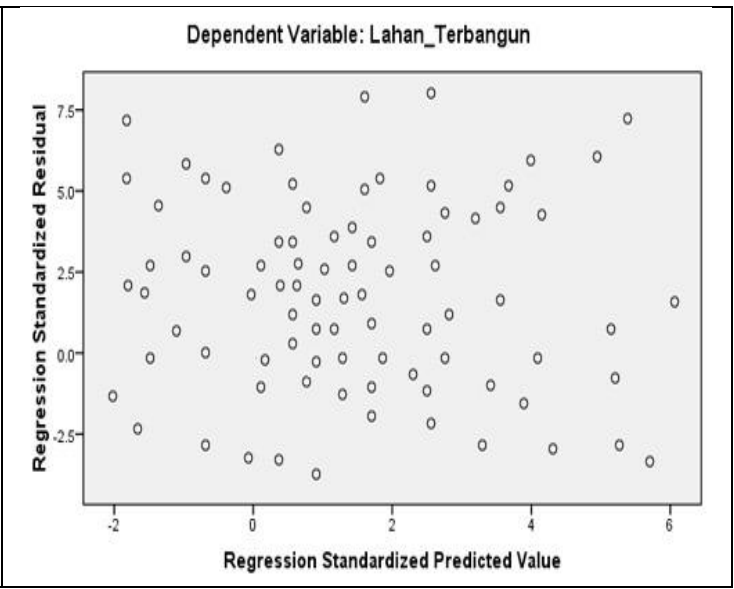

b. Data 2018

Gambar 10. Scatter plot of heteroscedaticity test.

Tabel 5. Hasil uji metode Durbin Watson.

\begin{tabular}{cccc}
\hline Data & $\boldsymbol{R}$ & $\boldsymbol{R}$ Square & Durbin-Watson \\
\hline 2013 & $0,847^{\mathrm{a}}$ & 0,722 & 2,244 \\
2018 & $0,975^{\text {a }}$ & 0,950 & 2,049 \\
\hline
\end{tabular}

\subsection{Uji kelayakan model}

Berikut adalah Tabel 6 hasil uji anova dari analisis regresi linier berganda.

Tabel 6. Hasil uji anova.

\begin{tabular}{cccccc}
\hline Model & Sum of Squares & $d f$ & Mean Square & $\boldsymbol{F}$ & Sig. \\
\hline 1 & 5641665.035 & 13 & 433974.233 & 94.389 & 0.000 \\
2 & 304234.137 & 13 & 23402.626 & 1.848 & 0.000 \\
\hline
\end{tabular}

Berdasarkan hasil uji kelayakan model didapatkan bahwa

a. Pada tabel 6, nilai sig anova pada kedua data adalah 0,000 lebih kecil daripada nilai signifikasi $5 \%$ atau 0,05 sehingga model regresi layak digunakan.

b. Hasil uji t pada table 4, semua variabel bebas pada kedua kelompok data memiliki nilai probabilitas kurang dari nilai signifikasi $5 \%$ atau 0,05 yang artinya memiliki pengaruh signifikan dengan tingkat keyakinan sebesar $95 \%$.

c. Nilai $R$ Square pada kedua kelompok data adalah 0,722 dan 0,975 . Sisanya yaitu sebesar 27,8\% (100\%-72,2\%) pada data 2013 dan sisa sebesar 2,5\% (100\%-97,5\%) pada data 2018. Sisa tersebut menunjukkan variabel yang sebenarnya berpengaruh terhadap luas longsor namun tidak terdapat dalam model yang dihasilkan. 


\subsection{Interpretasi model}

Model yang dihasilkan dari analisis regresi linier berganda pada kedua kelompok data sudah layak untuk digunakan karena lolos dalam uji asumsi klasik dan uji kelayakan model. Berikut kedua model yang dihasilkan dari analisis regresi linier berganda :

a. Model 1 (Data 2013)

$$
\begin{aligned}
& Y=101,82+18.05 \times 1+10,57 \times 2+(-1,22) \times 3+(-27,7) X 4+(-0,68) \times 5+(-3,49) \times 6+(-96,60) \\
& X 7+0,78 \times 8+0,35 \times 9+(-0,01) \times 10+0,01 \times 11+(-0,03) X 12+(-0,20) \times 13
\end{aligned}
$$

b. Model 2 (Data 2018)

$$
\begin{aligned}
& Y=19,77+3,67 \times 1+1,97 \times 2+(-0,97) \times 3+(-4,54) X 4+(-1,25) X 5+(-0,67) \times 6+(-10,11) \\
& X 7+(-0,19) X 8+0,86 \times 9+(-0,01) \times 10+0,026 \times 11+0,01 \times 12+1,50 \times 13
\end{aligned}
$$

Keterangan :

$\mathrm{Y}=$ Luas Lahan Terbangun (ha)

$\mathrm{X} 1=$ Kepadatan Penduduk (\%)

$\mathrm{X} 2=$ Kekuatan Pusat Aktivitas (skoring)

$\mathrm{X} 3=$ Jarak Setiap Desa dengan Pusat Aktivitas $(\mathrm{km})$

$\mathrm{X} 4=$ Jarak Setiap Desa dengan Jalan Kolektor Terdekat $(\mathrm{km})$

$\mathrm{X} 5=$ Jarak Setiap Desa dengan Jalan Nasional Terdekat $(\mathrm{km})$

$\mathrm{X} 6=$ Jarak ke Sungai Terdekat $(\mathrm{km})$

$\mathrm{X} 7 \quad=$ Kemiringan Rata-rata $(\mathrm{km})$

$\mathrm{X} 8=$ Luas Badan Air (ha)

X9 = Lahan Terbuka (ha)

$\mathrm{X} 10=$ Luas Pepohonan Lebat (ha)

$\mathrm{X} 11=$ Luas Pepohonan Sedang (ha)

$\mathrm{X} 12=$ Luas Rumput dan Semak (ha)

$\mathrm{X} 13=$ Luas Sawah (ha)

Jika diperhatikan pada kedua model tersebut memiliki karakter koefisien dan konstanta yang jauh berbeda. Pada model 1 nilai konstanta lebih besar dari pada model kedua yakni 101,82 dan sebagian besar koefisiennya memiliki arah negatif atau berbanding terbalik yakni sebanyak 7 variabel. Variabel yang memiliki koefisien paling tinggi adalah variabel X7 yakni kemiringan rata-rata, dengan nilai koefisien 96,60 dan berarah negatif atau berbanding terbalik. Artinya jika semakin rendah nilai kemiringan rata-rata suatu desa maka luas lahan terbangun akan semakin besar. Selain itu variabel yang memiliki nilai pengaruh paling rendah adalah variabel X10 dan X11 yakni luas pepohonan lebat dan luas pepohonan sedang dengan koefisien sebesar 0,01 . Namun variabel X10 memiliki nilai koefisien negatif sedangkan variabel X11 memiliki koefisien positif.

Pada model 2 terdapat 6 variabel dengan koefisien berarah positif dan 7 variabel dengan koefisien berarah negatif. Nilai konstanta pada model 2 lebih kecil yakni sebesar 19,77. Variabel koefisien terbesar adalah sama dengan model 1 yakni variabel X7 (kemiringan ratarata) yang memiliki nilai koefisien sebesar $-10,11$. Sedangkan variabel yang memiliki koefisien terkecil adalah X10 (luas pepohonan lebat) dan X12 (luas rumput dan semak) dengan nilai 
koefisien masing-masing adalah -0,01 dan 0,01. Perbedaan pada kedua model tersebut terletak pada nilai konstanta dan nilai koefisien serta arahnya. Variabel yang memiliki perbedaan arah dari kedua model tersebut adalah variabel X8 (luas badan air) dan X12 (luas rumput dan semak).

\section{Kesimpulan}

Pada tahun 2013, awal pertumbuhan kota yang dicirikan dengan adanya lahan terbangun di setiap desa sangat dipengaruhi oleh faktor X7 yakni kemiringan lahan (berbanding terbalik), $\mathrm{X} 1$ yakni kepadatan penduduk (berbanding lurus), $\mathrm{X} 4$ yakni jarak titik pusat desa dengan jalan kolektor terdekat (berbanding terbalik), dan X2 yakni kekuatan pusat aktivitas di suatu kecamatan (berbanding lurus). Sedangkan pada tahun 2018 beberapa variabel yang dinilai memiliki pengaruh paling tinggi adalah sama dengan variabel yang paling berpengaruh terhadap bertambahnya luas lahan terbangun pada tahun 2013. Namun koefisiennya lebih rendah jika dibandingkan dengan variabel pada tahun 2013.

Dari keseluruhan variabel terdapat beberapa variabel yang memiliki perbedaan arah koefisien yakni pada variabel X8 (luas badan air) dan X12 (luas rumput dan semak). Pada tahun 2013 luas badan air memiliki nilai koefisien positif artinya, jika luas badan air disuatu kawasan semakin luas maka minat masyarakat untuk mendirikan bangunan didesa tersebut akan semakin tinggi. Namun, hal tersebut berbanding terbalik pada tahun 2018 , begitu juga dengan variabel rumput dan semak yang mengalami perubahan arah koefisien pada tahun 2018. Model yang terbentuk tersebut dapat dijadikan rekomendasi dalam pengendalian pertumbuhan kota (urban growth) di Kabupaten Manggarai Timur sebagai wilayah administrasi baru (startup) bahwa untuk mengendalikan pertumbuhan kota lebih diprioritaskan pada pengendalian jumlah penduduk, karena variabel kepadatan penduduk dari kedua model tersebut paling berpengaruh terhadap pertumbuhan kota. Sedangkan variabel yang paling berpengaruh lainnya yakni kemiringan lahan, yang tidak memungkinkan dikendalikan kecuali melibatkan teknologi konstruksi.

\section{Referensi}

[1] Darlen M F, Hadi S dan Ardiansyah M 2015 Pengembangan Wilayah Berbasis Potensi Unggulan di Kabupaten Manggarai Timur Provinsi NTT sebagai Daerah Otonom Baru Jurnal Tata Loka 171 pp 37-52 DOI: 10.14710/tataloka.17.1.37-52

[2] Priambudi B N dan Pigawati B 2014 Faktor-Faktor yang Mempengaruhi Perubahan Pemanfaatan Lahan dan Sosial Ekonomi di Sekitar Apartemen Mutiara Garden Jurnal $\begin{array}{lllllll}\text { teknik } & \text { PWK } & 3 & 4 & \text { pp } & 576-84 & \text { Diakses dari }\end{array}$ https://ejournal3.undip.ac.id/index.php/pwk/article/view/6680/6751

[3] Duranton G 2004 Urban Evolutions: the Still, the Fast, and the Slow Working paper (London: Department of Geography and Environment, London School of Economics)

[4] Prihatin R B 2015 Alih Fungsi Lahan di Perkotaan (Studi Kasus di Kota Bandung dan Yogyakarta) Pusat Pengkajian, Pengolahan Data dan Informasi (P3DI) Sekretariat Jenderal DPR RI 62 pp 105-18 DOI: 10.22212/aspirasi.v6i2.507 
[5] Hasyim A W, Gusti H I K and Prayitno G 2020 Determination Of Land Cover As Landslide Factor Based On Multitemporal Raster Data In Malang Regency International Journal of GEOMATE $18 \quad 69 \quad \mathrm{pp} \quad 254-61$ Diakses dari https://www.geomatejournal.com/node/1825

[6] Navastara A M, Mahriyar M Z dan Bintang C A 2010 Konsep Compact City sebagai Salah Satu Konsep Inovatif Perencanaan Tata Ruang dalam Menyelesaikan Masalah Pembangunan di Kota Surabaya ITS Scientific Articles Teknik Perencanaan Wilayah dan Kota Diakses dari http://digilib.its.ac.id/ITS-Article-3400012000264/18162

[7] Zahrotunisa S dan Wicaksono P 2017 Prediksi Spasial Perkembangan Lahan Terbangun Melalui Pemanfaatan Citra Landsat Multitemporal di Kota Bogor Jurnal Online Informatika (JOIN) 21 pp 30-5 DOI: 10.15575/join.v2i1.88

[8] Cullingswoth J B AND Caves R 1997 Planningin the USA: Policies, Issues and Processes (London, New York: Routledge)

[9] Chapin F S, Kaiser E J dan Godschalk D R 1979 Urban Land Use Planning (Urbana: University of Illnois Press) 